\title{
External radiation exposure of the Angolan population living in adobe houses
}

\author{
Judith Salupeto-Dembo ${ }^{1} \cdot$ Zsuzsanna Szabó-Krausz $^{1,2} \cdot$ Péter Völgyesi $^{3} \cdot$ Zoltán Kis $^{4} \cdot$ Csaba Szabó $^{1}$
}

Received: 30 August 2019 / Published online: 25 November 2019

(c) The Author(s) 2019

\begin{abstract}
This study aims to investigate the radioactivity of adobe in Angola, where it is a widely used building material. Sixty samples have been collected from three remote areas of the country with different geological backgrounds (Cabinda, Huambo, Menongue). Activity concentrations of ${ }^{226} \mathrm{Ra},{ }^{232} \mathrm{Th}$ and ${ }^{40} \mathrm{~K}$ have been determined by gamma-ray spectroscopy and radiation hazard indices were also calculated. The area Huambo shows elevated ${ }^{226} \mathrm{Ra}$ and ${ }^{232} \mathrm{Th}$ values which can be explained by its older geological formations. ${ }^{40} \mathrm{~K}$ concentrations are low in general. Regarding external radiation risk, adobe from Angola is safe to use as building material.
\end{abstract}

Keywords Environmental radioactivity $\cdot$ Geology $\cdot$ Adobe $\cdot$ Building material $\cdot$ Gamma-ray spectroscopy

\section{Introduction}

Radiation exposure originates mainly from natural sources [1]. Human population is exposed to two types of natural radiation: (1) internal exposure is due to inhalation or ingestion of radionuclides which release alpha, beta and gamma radiation inside the human body, (2) external exposure is mostly due to the more penetrable gamma radiation from surrounding environment. Amongst natural sources contributing to external exposures, terrestrial radionuclides and cosmic radiation are the biggest contributors [1,2]. Building materials also significantly contribute to the exposure of the population to natural radioactivity [3] as they contain terrestrial radionuclides. The main radionuclides responsible for

Csaba Szabó

cszabo@elte.hu

1 Lithosphere Fluid Research Lab, Department of Petrology and Geochemistry, Eötvös Loránd University, Pázmány Péter s. 1/C, Budapest 1117, Hungary

2 Premium Postdoctorate Research Program, Hungarian Academy of Sciences, Budapest, Hungary

3 Nuclear Security Department, Centre for Energy Research, Hungarian Academy of Sciences, Konkoly Thege Miklós u.,29-33, Budapest 1121, Hungary

4 Nuclear Analysis and Radiography Department, Centre for Energy Research, Hungarian Academy of Sciences, Konkoly Thege Miklós u.,29-33, Budapest 1121, Hungary terrestrial radiation are the members of the ${ }^{238} \mathrm{U}$ and ${ }^{232} \mathrm{Th}$ series together with ${ }^{40} \mathrm{~K}[1,2]$. From radiological point of view the relatively long half-life (1640 years) and the widespread abundance in the environment make ${ }^{226} \mathrm{Ra}$ and its decay products the most important isotopes in the ${ }^{238} \mathrm{U}$ decay chain. Therefore, concentrations of these radionuclides significantly affect the radiation exposure of the population, which varies from place to place depending mostly on the geology of the studied areas.

Many investigations on natural radioactivity of building materials have been carried out worldwide. These studies contributed to the elaboration of regulations applicable nationally or regionally [2, 4-7]. In Africa, only a few countries followed the path of detailed investigation of natural radioactivity. Reviewing studies made in Africa, highly different results can be found depending on the focus of the research. For example, taking as reference the worldwide median of UNSCEAR [7], activity concentrations of primordial radionuclides in soil are in the range of the reference in Zambian building materials from Lusaka [8], but higher in Namibian soils [9]. In terms of dose, in Cameroon, an investigation on rocks and soils for outdoor effective dose rates showed variable results depending on the geology of the studied area, reaching values three to four times higher than the recommended limit of $0.07 \mathrm{mSv}$ year ${ }^{-1}$ by the UNSCEAR [10, 11]. In Kenya, studies have also shown annual effective doses higher than the reference in certain areas $[12,13]$. 
As seen above, natural radiation in Africa varies considerably depending on the location. In Angola, there is no record of studies on natural radiation. Adobe is one of the most used building materials both in villages and suburban areas, and it is the most widespread building material of families with low income. It is easily accessible, and it has an advantage of keeping a favorable indoor temperature in tropical climate. In this work, the studied building material is adobe and the focus of the study is the contribution of this building material to external radiation exposure. Adobes are made of soil and water, sometimes mixed with organic matter, and dried at ambient conditions. Because of the simple manufacturing of adobes, they preserve the radionuclide content of the source soil. It is important to note that soil composition is determined by the geological composition of the mother rock.

This study aims to determine the activity concentrations of ${ }^{226} \mathrm{Ra}$, ${ }^{232} \mathrm{Th}$ and ${ }^{40} \mathrm{~K}$ in Angolan adobe, and evaluate the risk of external exposure of the population living in adobe houses. Another aim is to classify the building materials by using international indexes like the radium equivalent index $\left(\mathrm{Ra}_{\mathrm{eq}}\right)$ and the activity concentration index (I). Taking into account local differences on the background radiation, gamma dose rates measured in situ and those calculated from the activity concentrations of the radionuclides, found in the building materials, are compared. Being the first such research done in Angola, it will contribute to the Angolan and African natural radioactivity database, serving as reference for further studies.

\section{Studied areas}

Angola is the sixth biggest African country with a $1,246,700 \mathrm{~km}^{2}$ area. The western part of the country is surrounded by the Atlantic Ocean along a $1650 \mathrm{~km}$ long coastline. The geographical landscape of the country varies from north to south as follows; a tropical forest at the north part, a fine coastal line along the ocean, an interior plateau in the center, and a dry savannah from south to south east.

Three different areas were chosen for this study based on their different geographical position and geological background. These are Cabinda at the north, Huambo in the central part and Menongue more towards the south (Fig. 1). These three localities belong to three different provinces. Below an overview of each province is provided. The information summarized is mostly from "Notícia Explicativa da Carta Geologica de Angola", a summary of the geology of Angola made by the National Institute of Geology in 1977, which was reviewed and updated in 1992 [14]. It is important to note that the reconstitution of the Angolan Geological map is still ongoing.

\section{Cabinda}

In Angola most of the main cities have the same name as the province they belong to. This is the case of Cabinda which is the main city of the Cabinda province. It is located at $12^{\circ} 12^{\prime}$ $\mathrm{E}$ and $5^{\circ} 30^{\prime} \mathrm{S}$ with a mean altitude of $1 \mathrm{~m}$ above sea level (Fig. 1). The province of Cabinda is an enclave located at the North-West part of the country. Its climate is tropical humid.

The geology of the province is characterized by various formations aging from Precambrian to Holocene, including Pleistocene marine deposits at the coastal area.

\section{Huambo}

Huambo is the capital city of the Huambo province. It is located $1700 \mathrm{~m}$ above the sea and the coordinates are $15^{\circ} 45^{\prime}$ $\mathrm{E}$ and $12^{\circ} 48^{\prime} \mathrm{S}$ (Fig. 1). The province of Huambo is located at the central part of the country. Its climate is tropical highly influenced by the altitude and the cold current of Benguela.

The geology of the province consists of old (Archean to Proterozoic) metamorphic (gneiss, micaschist, metasediments) and igneous (granite, rhyolite to andesites) rocks. At Huambo city Paleocene-Eocene laterites were also mapped.

\section{Menongue}

Menongue is the main city of the Cuando Cubango province. It is located at $17^{\circ} 41^{\prime} \mathrm{E}$ and $14^{\circ} 39^{\prime} \mathrm{S}$ with an elevation of $1300 \mathrm{~m}$ above sea level (Fig. 1). The province of Cuando Cubango is located at the south west part of the country. Its climate is semi-desert influenced by the desert of Namibe.

Its geology is based on Archean mostly gneiss and Proterozoic rhyolite-andesite and Tertiary-Quaternary Kalahari sediment formations.

\section{Materials and methods}

\section{In-situ ambient gamma dose rate}

The portable device FH 40 G-L10 (Thermo Fisher Scientific Inc.) was used to perform the in situ ambient gamma dose equivalent rate measurements. The detection limit of the mentioned survey meter goes from $10 \mathrm{nSvh}^{-1}$ to $100 \mathrm{mSvh}^{-1}$ and from $30 \mathrm{keV}$ to $4.4 \mathrm{MeV}$ regarding the gamma energies. Measurements were done in the living rooms of 45 houses at two or three different points, at $1 \mathrm{~m}$ height.

\section{Building material sampling}

A total of 60 adobe samples were collected in the three study areas, making 20 per area. The materials were sampled from (i) pieces of remaining adobes after construction, (ii) pieces 

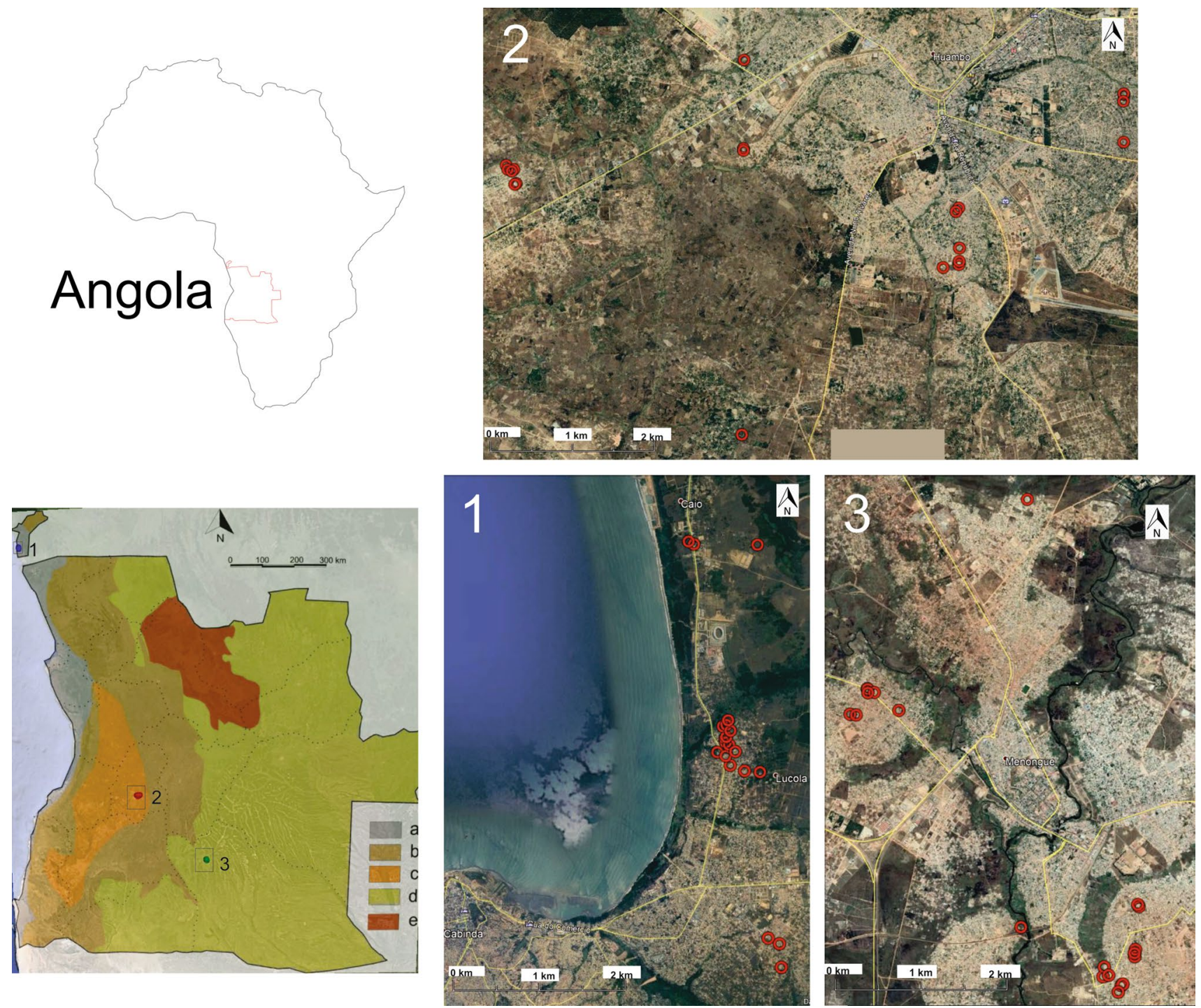

Fig. 1 Sampling points in (1) Cabinda, (2) Huambo and (3) Menongue on the sketch of the geological map of Angola [14]. Geological features on the map are as follows, (a) Pleistocene to Cretaceous

took directly from houses, and (iii) soil used to make the adobe, in a few cases. The sampling sites were selected randomly within the studied cities (Fig. 1).

\section{Sample preparation}

The sample preparation was carried out in the Lithosphere Fluid Research Lab at the Eötvös Loránd University, Budapest. Samples were dried at lab temperature (around $20^{\circ} \mathrm{C}$ ) at least for a month. Then they were powdered and sieved below $0.5 \mathrm{~mm}$ diameter to ensure homogeneity. Afterwards the homogeneous samples were dried in an oven at $40{ }^{\circ} \mathrm{C}$ until constant weight is reached. marine sediments, (b) Archean to Proterozoic rocks, (c) Belts of the upper Proterozoic (Pan-African of age), (d) Sedimentary from Tertiary to Quaternary, (e) Mesozoic to Paleozoic sediments

The dry, homogeneous samples were poured into sample holders made of High-Density Polyethylene (HDPe) which are proven to be radon-tight [15]. There was a need to artificially compact the sample in the sample holder in order to avoid a later self-compaction, because it could have led to an empty space inside the sample holder where ${ }^{222} \mathrm{Rn}$ can accumulate. Such inhomogeneity leads to false results [15]. After the filling, samples were left on rest for a minimum of 30 days to ensure the secular equilibrium between ${ }^{226} \mathrm{Ra},{ }^{222} \mathrm{Rn}$ and its daughters. 


\section{Gamma-ray spectroscopy}

Gamma-ray spectroscopy measurements were carried out at the Centre for Energy Research, Hungarian Academy of Sciences, Budapest. An n-type HPGe detector (Canberra GR1319) with a relative efficiency of $13 \%$, and a Canberra DSA-2000 acquisition system were used with a low background chamber [15]. The energy resolution (FWHM) is 1.53 and $1.99 \mathrm{keV}$ at 662 and $1332 \mathrm{keV}$, respectively. The peak-to-Compton ratio is $42.8: 1$ at $1332 \mathrm{keV}$. Dead-time losses during the experiments never exceeded $0.05 \%$. The efficiency transfer method was applied for the determination of the full-energy-peak efficiency for the extended samples in close-in geometry. More details on the measurement method are explained by Kis et al. [15].

Samples were measured for 42-120 h (samples with lower radioactivity needed more time) to reach good statistics. The determination of ${ }^{226} \mathrm{Ra}$ was made from gamma lines of ${ }^{222} \mathrm{Rn}$ daughters, ${ }^{214} \mathrm{~Pb}(242,295$ and $352 \mathrm{keV})$ and ${ }^{214} \mathrm{Bi}(609,1120$ and $1765 \mathrm{keV})$, assuming the secular equilibrium inside the sample holder. ${ }^{232} \mathrm{Th}$ was evaluated using gamma lines of ${ }^{212} \mathrm{~Pb}$ (239 and $300 \mathrm{keV}$ ) and ${ }^{228} \mathrm{Ac}$ (338, 463, 911, 965 and $969 \mathrm{keV})$ assuming the secular equilibrium in the ${ }^{232} \mathrm{Th}$ chain as well. K-40 was evaluated from its own peak (1461 keV).

\section{Hazard indexes calculations}

For the qualification and classification of building materials, hazard indexes were determined from the activity concentrations of ${ }^{226} \mathrm{Ra}\left(\mathrm{C}^{226} \mathrm{Ra}\right),{ }^{232} \mathrm{Th}\left(\mathrm{C}^{232} \mathrm{Th}\right)$ and ${ }^{40} \mathrm{~K}$ (C $\left.\mathrm{C}^{232} \mathrm{Th}\right)$.

\section{Radium equivalent index $\left(\mathrm{Ra}_{\mathrm{eq}}\right)$}

Radium equivalent index $\left(\mathrm{Ra}_{\mathrm{eq}}\right.$ in $\left.\mathrm{Bq} \mathrm{kg}{ }^{-1}\right)$ is one of the most commonly used indexes in literature. This index allows to calculate the specific activity concentration of the sample and to evaluate the radiation hazard associated to it. The equation below (Eq. 1) determining the $\mathrm{Ra}_{\mathrm{eq}}$ index is established considering that $370 \mathrm{~Bq} \mathrm{~kg}^{-1}$ of ${ }^{226} \mathrm{Ra}^{2}$, $299 \mathrm{~Bq} \mathrm{~kg}^{-1}$ of ${ }^{232} \mathrm{Th}$ and $4810 \mathrm{~Bq} \mathrm{~kg}^{-1}$ of ${ }^{40} \mathrm{~K}$ produce the same gamma dose rate. Limit values of $\mathrm{Ra}_{\mathrm{eq}}$ are the following: for building materials $370 \mathrm{~Bq} \mathrm{~kg}^{-1}$ [16] to keep the external dose below $1.5 \mathrm{mSv}_{\text {year }}{ }^{-1}$, for industrial use $740 \mathrm{~Bq} \mathrm{~kg}^{-1}$, for roads and railways $2200 \mathrm{~Bq} \mathrm{~kg}^{-1}$, for landfill materials $3700 \mathrm{~Bq} \mathrm{~kg}^{-1}$.

$\mathrm{Ra}_{\mathrm{eq}}=\mathrm{C}_{226 \mathrm{Ra}}+\frac{10}{7} \mathrm{C}_{232 \mathrm{Th}}+\frac{10}{130} \mathrm{C}_{40 \mathrm{~K}}$

\section{Activity concentration index I}

The unitless activity concentration index (I, Eq. 2) recommended by the Radiation Protection (RP)112 [17], was applied for further comparison purposes. Calculation of this index is based on the following assumptions: the room size is $4 \mathrm{~m} \times 5 \mathrm{~m} \times 2.8 \mathrm{~m}$, all structures (walls, floor and ceiling) are made of the same material with density of $2350 \mathrm{~kg} \mathrm{~m}^{-3}$, no windows or doors exist, and it also takes into account a background cosmic and terrestrial dose rate of $50 \mathrm{nG}$ year $\mathrm{h}^{-1}$ [17]. The main aim of this index is to show whether the annual dose due to the excess external gamma radiation in a building may exceed $1 \mathrm{mSv}$ year ${ }^{-1}$ [17]. For materials used in bulk amounts the recommended limit of this index is $\mathrm{I} \leq 1$, whilst for materials with restricted usage it is $\mathrm{I} \leq 6$.

$I=\frac{\mathrm{C}_{226} \mathrm{Ra}}{300}+\frac{\mathrm{C}_{232} \mathrm{Th}}{200 \mathrm{~Bq} \mathrm{~kg}^{-1}}+\frac{\mathrm{C}_{40} \mathrm{~K}}{3000 \mathrm{~Bq} \mathrm{~kg}^{-1}}$

\section{Dose estimations}

In this work annual effective doses (AED) were determined in two distinct ways: in the first method it was determined from the in situ ambient gamma dose equivalent rate measurements (AED-measured) and in the other it was calculated from the activity concentrations of ${ }^{226} \mathrm{Ra},{ }^{232} \mathrm{Th}$ and ${ }^{40} \mathrm{~K}$ of the building material (AED-calculated).

\section{In-situ ambient gamma dose equivalent rate measurements (AED-measured)}

The AED-measured was determined by converting the ambient gamma dose equivalent rate values measured in situ from $\mathrm{nSv} \mathrm{h}{ }^{-1}$ to $\mathrm{mSv}$ year $^{-1}$.

\section{Calculated annual effective dose (AED-calculated)}

The AED-calculated ( $\mathrm{D}_{\mathrm{e}}$ in $\mathrm{mSv}$ year ${ }^{-1}$; Eq. 3 ) was determined from the absorbed dose rate $\left(\mathrm{D}_{\mathrm{a}}\right.$ in $\mathrm{nG}$ year $\left.\mathrm{h}^{-1}\right)$ taking into account the annual indoor occupancy time $(\mathrm{T}=0.8$ $\left.\times 24 \mathrm{~h} \times 365.25 \mathrm{~d}=7012.8 \mathrm{~h}_{\text {year }}{ }^{-1}\right)$ and the dose conversion factor $\left(\mathrm{F}=0.7 \mathrm{SvG}_{\mathrm{year}}{ }^{-1}\right)$ [17]. According to the RP 112 [17], $\mathrm{D}_{\mathrm{a}}$ can be calculated from the equation below (Eq. 4) if we consider a room with dimensions of $4 \mathrm{~m} \times 5 \mathrm{~m} \times 2.8 \mathrm{~m}$, wall thickness of $20 \mathrm{~cm}$ and wall density of $2350 \mathrm{~kg} \mathrm{~m}^{-3}$. A $50 \mathrm{nG}$ year $\mathrm{h}^{-1}$ background radiation is assumed.

$D_{e}=10^{-6} T F D_{a}$

$D_{a}=0.92 \mathrm{C}_{226 \mathrm{Ra}}+1.1 \mathrm{C}_{232 \mathrm{Th}}+0.08 \mathrm{C}_{40} \mathrm{~K}$ 


\section{Statistics}

Descriptive statistics as mean, average and standard deviation have been determined using the software program "Origin". The data also have been summarized in box and whisker plots for a comparison of the results obtained at different studied locations.

Pearson correlation coefficients [18] have been determined for the variables using the software program "Statgraphics". All the statistical tests were performed at the 95\% confidence level, in this program.

\section{Results}

\section{Measured ${ }^{226} \mathrm{Ra},{ }^{232} \mathrm{Th}$ and ${ }^{40} \mathrm{~K}$ activity concentrations}

Average and standard deviations of the activity concentrations in $\mathrm{Bq} \mathrm{kg}^{-1}$ are $26 \pm 7,36 \pm 5,45 \pm 17$ in Cabinda, $87 \pm 20,81 \pm 21,82 \pm 15$ in Huambo and $27 \pm 10,30 \pm 10$, $73 \pm 40$ in Menongue for ${ }^{226} \mathrm{Ra},{ }^{232} \mathrm{Th}$ and ${ }^{40} \mathrm{~K}$, respectively (Table 1; Fig. 2a-c).

Table 1 Summary of averages, standard deviations and ranges of activity concentrations, Radium equivalent index $\left(\mathrm{Ra}_{\mathrm{eq}}\right)$, I index and calculated and measured annual effective doses

\begin{tabular}{|c|c|c|c|c|c|c|c|c|}
\hline \multirow[t]{2}{*}{ Location } & & \multicolumn{3}{|c|}{$\begin{array}{l}\text { Activity concentrations } \\
\left(\mathrm{Bq} \mathrm{kg}^{-1}\right)\end{array}$} & \multirow[t]{2}{*}{$\mathrm{Ra}_{\mathrm{eq}}\left(\mathrm{Bq} \mathrm{kg}^{-1}\right)$} & \multirow[t]{2}{*}{ I index } & \multirow[t]{2}{*}{$\begin{array}{l}\text { Annual effective dose- } \\
\text { measured }\left(\mathrm{mSv} \text { year }^{-1}\right)\end{array}$} & \multirow{2}{*}{$\begin{array}{l}\text { Annual effective } \\
\text { dose-calculated } \\
\left(\mathrm{mSv} \text { year }{ }^{-1}\right)\end{array}$} \\
\hline & & ${ }^{226} \mathrm{Ra}$ & ${ }^{232} \mathrm{Th}$ & ${ }^{40} \mathrm{~K}$ & & & & \\
\hline \multirow[t]{2}{*}{ Cabinda } & Average & $26 \pm 7$ & $36 \pm 5$ & $45 \pm 17$ & $81 \pm 13$ & $0.28 \pm 0.05$ & $0.6 \pm 0.13$ & $0.4 \pm 0.06$ \\
\hline & Range & $45-15$ & $49-27$ & $92-28$ & $121-56$ & $0.42-0.19$ & $0.86-0.48$ & $0.50-0.22$ \\
\hline \multirow[t]{2}{*}{ Huambo } & Average & $87 \pm 15$ & $81 \pm 21$ & $82 \pm 15$ & $209 \pm 45$ & $0.72 \pm 0.15$ & $1.5 \pm 0.32$ & $0.8 \pm 0.2$ \\
\hline & Range & $116-49$ & $121-39$ & $105-50$ & $273-113$ & $0.95-0.39$ & $2.28-1.12$ & $1.11-0.47$ \\
\hline \multirow[t]{2}{*}{ Menongue } & Average & $27 \pm 10$ & $30 \pm 10$ & $73 \pm 40$ & $76 \pm 24$ & $0.26 \pm 0.08$ & $1.04 \pm 0.16$ & $0.3 \pm 0.06$ \\
\hline & Range & $56-15$ & $57-17$ & $155-21$ & $145-44$ & $0.51-0.16$ & $1.24-0.64$ & $0.62-0.18$ \\
\hline
\end{tabular}
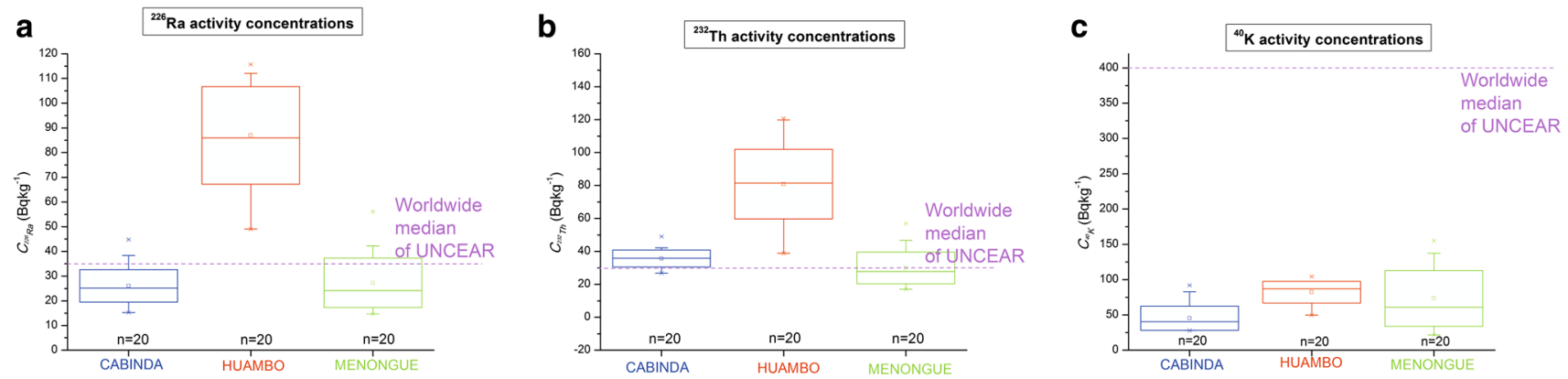

Fig. 2 Box and whisker plots of (a) ${ }^{226} \mathrm{Ra}$, (b) ${ }^{232} \mathrm{Th}$ and (c) ${ }^{40} \mathrm{~K}$ activity concentrations $\left(\mathrm{Bq} \mathrm{kg}^{-1}\right)$ of the studied adobes from the three different areas

Table 2 Correlations among the three studied radionuclides

\begin{tabular}{llll}
\hline Location & ${ }^{226} \mathrm{Ra}$ and ${ }^{232} \mathrm{Th}$ correlation & ${ }^{226} \mathrm{Ra}$ and ${ }^{40} \mathrm{~K}$ correlation & ${ }^{232} \mathrm{Th}$ and ${ }^{40} \mathrm{~K}$ correlation \\
\hline Cabinda & $\mathrm{R}=0.66$ & $\mathrm{R}=0.62$ & $\mathrm{R}=0.36$ \\
& $P$-value $=0.0014$ & $P$-value $=0.0036$ & $P$-value $=0.115$ \\
Huambo & $\mathrm{R}=0.55$ & $\mathrm{R}=0.19$ & $\mathrm{R}=0.5$ \\
& $P$-value $=0.012$ & $P$-value $=0.41$ & $P$-value $=0.023$ \\
Menongue & $\mathrm{R}=0.8$ & $\mathrm{R}=0.23$ & $\mathrm{R}=0.48$ \\
& $P$-value $=0.0001$ & $P$-value $=0.338$ & $P$-value $=0.0312$ \\
\hline
\end{tabular}




\section{Correlations among ${ }^{226} \mathrm{Ra},{ }^{232} \mathrm{Th}$ and ${ }^{40} \mathrm{~K}$ activity concentrations}

Correlations between ${ }^{226} \mathrm{Ra}$ and ${ }^{232} \mathrm{Th}$ was found to be 0.66 in Cabinda with a $P$ value of 0.0014 (Table 2; Fig. 3a), 0.55 in Huambo with a $P$-value of 0.012 (Table 2; Fig. 3 b) and 0.80 in Menongue with a $P$-value of 0.0001 (Table 2; Fig. 3c). According to this result, in all areas the mentioned radionuclides have a statistically significant relationship.

Correlations between ${ }^{226} \mathrm{Ra}$ and ${ }^{40} \mathrm{~K}$ show the following results: 0.62 with a $P$-value of 0.0036 in Cabinda (Table 2; Fig. 4a), 0.19 with a $P$-value of 0.41 in Huambo (Table 2; Fig. 4b) and 0.23 with a $P$-value of 0.338 in Menongue (Table 2; Fig. 4c). Statistically significant relationship is found in Cabinda, but not in the two other areas.
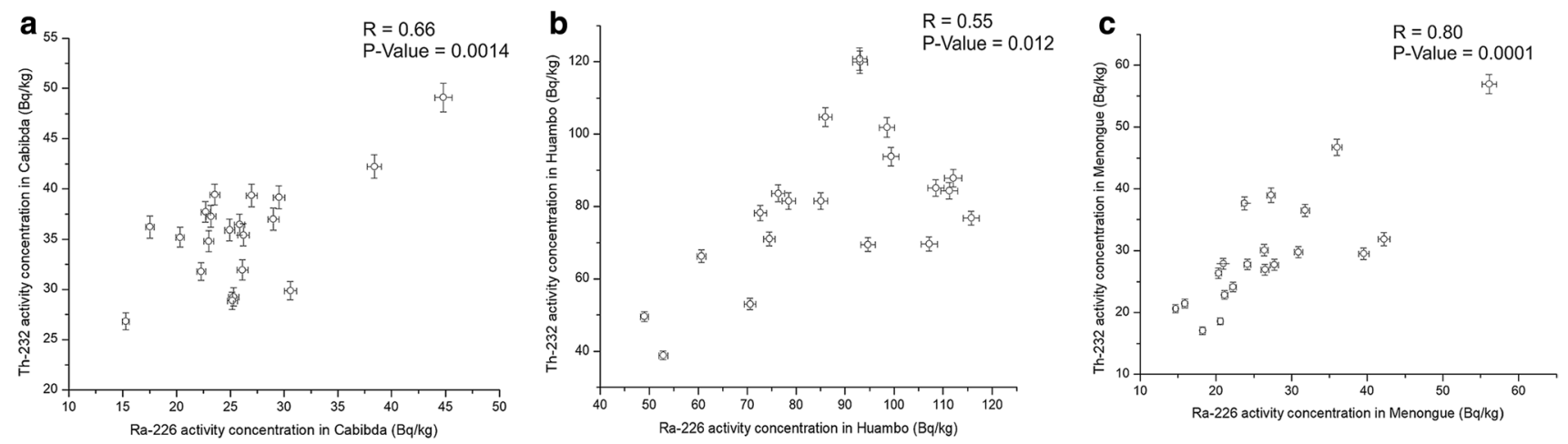

Fig. 3 Correlation between ${ }^{226} \mathrm{Ra}$ and ${ }^{232} \mathrm{Th}$ in a Cabinda, b Huambo and $\mathbf{c}$ Menongue
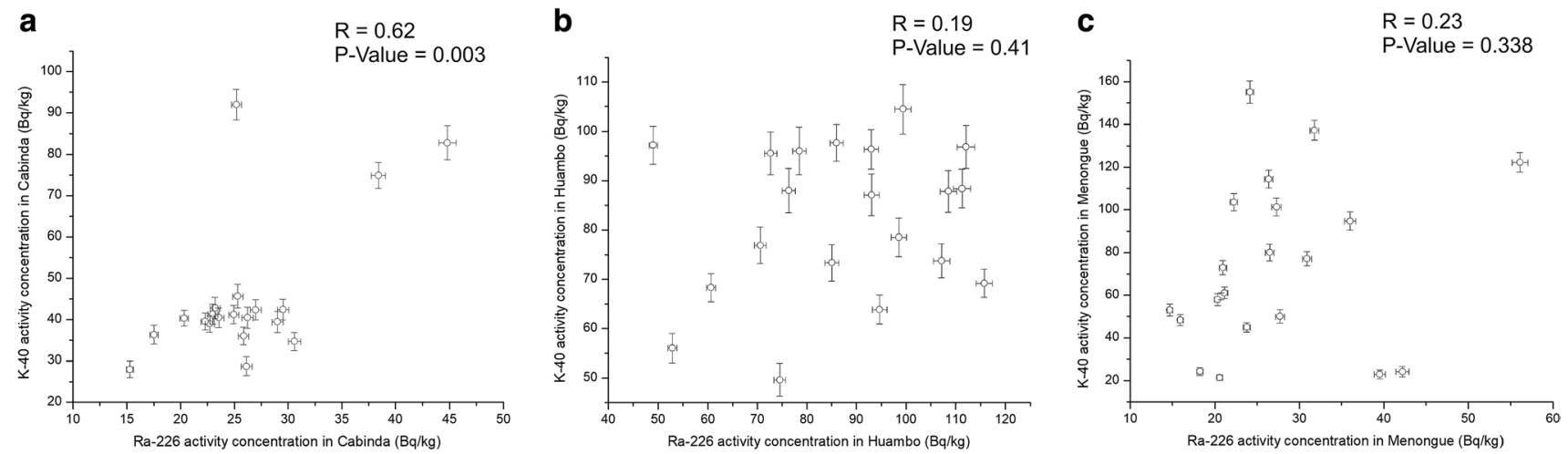

Fig. 4 Correlation between ${ }^{226} \mathrm{Ra}$ and ${ }^{40} \mathrm{~K}$ in a Cabinda, b Huambo and $\mathbf{c}$ Menongue
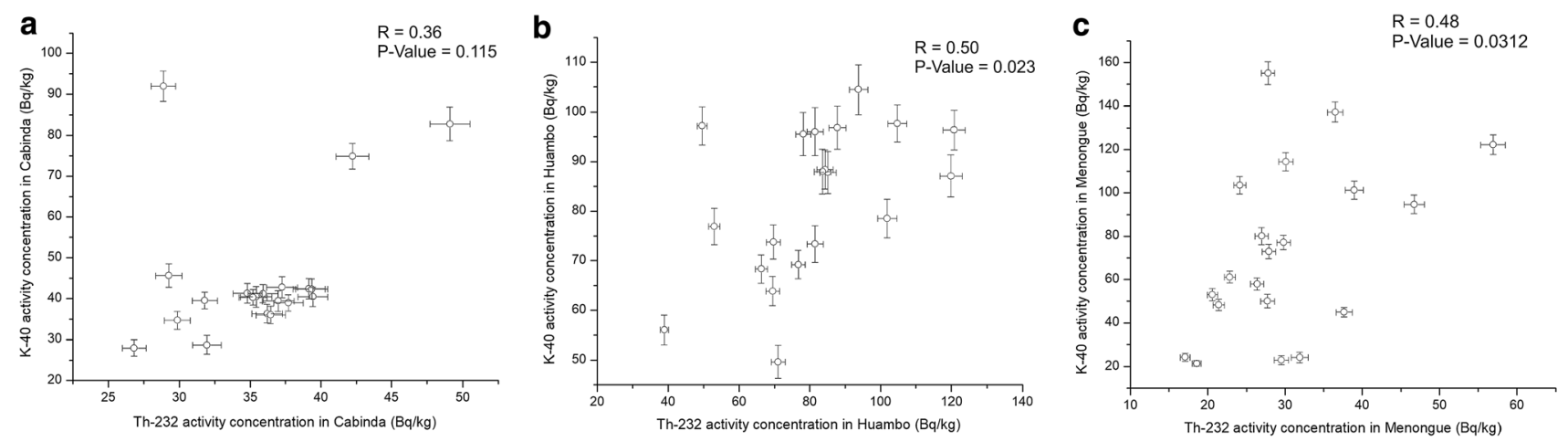

Fig. 5 Correlation between ${ }^{232} \mathrm{Th}$ and ${ }^{40} \mathrm{~K}$ in a Cabinda, b Huambo and $\mathbf{c}$ Menongue 
Results of correlations between ${ }^{232} \mathrm{Th}$ and ${ }^{40} \mathrm{~K}$ are as follows: 0.36 with a $P$-value of 0.115 in Cabinda (Table 2; Fig. 5a), 0.50 with a $P$-value of 0.023 in Huambo (Table 2; Fig. 5b) and 0.48 with a $P$-value of 0.0312 in Menongue (Table 2; Fig. 5c). Here we have statistically significant relationship in Huambo and Menongue, but not in Cabinda.

\section{$\mathrm{Ra}_{\mathrm{eq}}$ and I hazard indexes}

Averages and standard deviations of the $\mathrm{Ra}_{\mathrm{eq}}$ index are $81 \pm 13 \mathrm{~Bq} \mathrm{~kg}^{-1}$ in Cabinda, $209 \pm 45 \mathrm{~Bq} \mathrm{~kg}^{-1}$ in Huambo and $76 \pm 24 \mathrm{~Bq} \mathrm{~kg}^{-1}$ in Menongue. For the I index, averages and standard deviations are $0.28 \pm 0.05$ in Cabinda, $0.72 \pm 0.15$ in Huambo and $0.26 \pm 0.08$ in Menongue (Table 1; Fig. 6a, b).

\section{Doses}

Measured in situ ambient gamma dose equivalent rates present the following averages and respective standard deviations: $0.6 \pm 0.13,1.5 \pm 0.32$ and $1.04 \pm 0.16 \mathrm{mSv}_{\text {year }}{ }^{-1}$ in Cabinda, Huambo and Menongue, respectively (Table 1; Fig. 7). Averages of the annual doses calculated from the activity concentration of the radionuclides in building materials with respective standard deviation are: $0.4 \pm 0.06$, $0.8 \pm 0.2$ and $0.3 \pm 0.06 \mathrm{mSv}$ year $^{-1}$ in Cabinda, Huambo and Menongue, respectively (Table 1 ; Fig. 7).

\section{Discussion}

\section{Influence of geology on natural radiation in Angola}

The influence of geology on the spatial distribution of natural radiation has been proven by many studies [19-22]. Different gamma dose values can relate to different geological backgrounds [23-25]. It is important to recall that the studied building material (i.e., adobe) is made of the local soil, which develops via weathering process from the surrounded

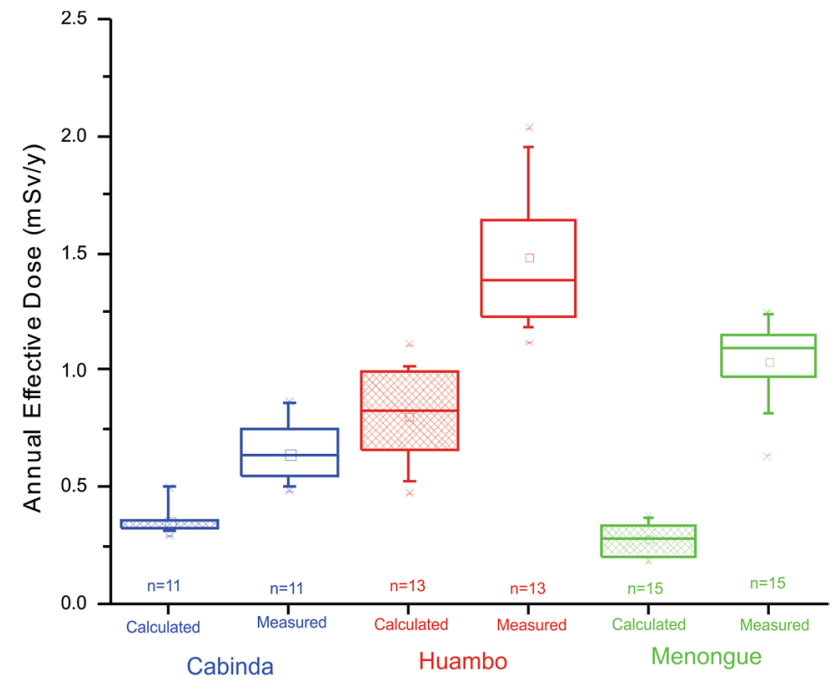

Fig. 7 Comparison between the effective doses calculated from activity concentration of the building materials (AED-calculated) and measured in situ (AED-measured); (1) AED-calculated, (2) AEDmeasured at the three different studied areas

rocks. The composition of the source rock eventually controls the natural radioactivity of the soils of the area [26] and therefore of adobes. Results of present study have shown different levels of radioactivity at the three studied areas of Angola that have different geological backgrounds [14]. As seen in the results, the North part (Cabinda) and the South part (Menongue) show the lowest average activity concentrations: $26 \pm 7,36 \pm 5,45 \pm 17$ and $27 \pm 10,30 \pm 10,73 \pm 40$ for ${ }^{226} \mathrm{Ra},{ }^{232} \mathrm{Th}$ and ${ }^{40} \mathrm{~K}$, respectively. Adobe samples collected in Cabinda are mostly made of soils derived from rocks belonging to Pleistocene marine sediment formations consisting mostly of sand deposits. Adobe samples from Menongue are from soils formed from rocks belonging to Eocene-Pliocene sand formations. In contrary, the central part of the country (Huambo) with Archean metamorphic (gneiss and micaschist) and Proterozoic metasediment formations shows the highest average activity concentrations
Fig. 6 Box and whisker plots of (a) the Radium Equivalent Index $\left(\mathrm{Bq} \mathrm{kg}^{-1}\right)$ and (b) the unitless activity concentration index I [17]
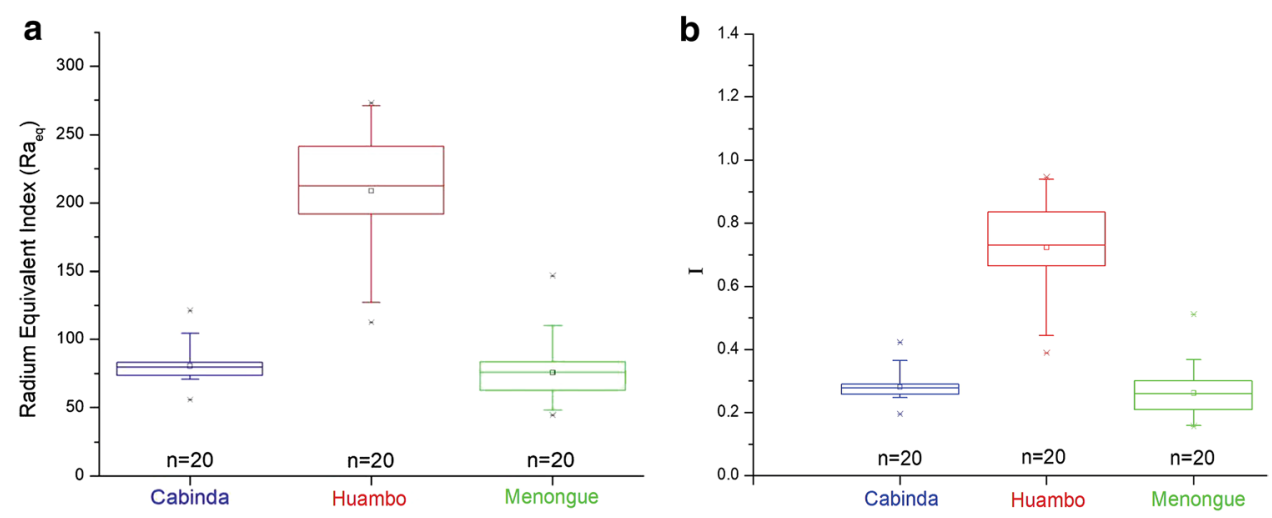
(Fig. 2a-c; [14]). The above described formations are known for their potential to contain elevated concentrations of radioactive minerals [27].

\section{Geochemistry of the studied radionuclides}

In order to understand the mutual effects of the three studied radionuclides, ${ }^{226} \mathrm{Ra},{ }^{232} \mathrm{Th}$ and ${ }^{40} \mathrm{~K}$, it is important to analyze their correlations and consequently, their relationships. The strongest correlation between ${ }^{226} \mathrm{Ra}$ and ${ }^{232} \mathrm{Th}$ is found in Menongue ( $\mathrm{R}=0.8$, Fig. 3c). The lithology made up of Eocene-Pliocene sediment formations in Menongue is rather homogeneous [14]. In areas with such a characterization, correlations between ${ }^{226} \mathrm{Ra}$ and ${ }^{232} \mathrm{Th}$ are expected to be high [28]. This strong correlation, found between ${ }^{226} \mathrm{Ra}$ and ${ }^{232} \mathrm{Th}$, may be explained by the similar geochemical behavior of the parent and progeny nuclides, which infers similar responses to the soil and environmental processes that affect their distribution [26]. Uranium and thorium have the same replacement capacity of a nucleus in the lattice of a mineral because of their radius length. Moreover, despite the fact that uranium tend to be more mobile than thorium during weathering processes, studies have proven the immobility of uranium due to adsorption or co-precipitation by amorphous Fe-oxyhydroxides [27]. Therefore, Dequincey et al. [29] had the same result of uranium and thorium accumulation in the indurated ferruginous cap of African laterites, and of their secondary redistribution into the profile.

Regarding the correlation between ${ }^{226} \mathrm{Ra}$ and ${ }^{40} \mathrm{~K}$, the only area with a statistically significant relationship is Cabinda (Fig. 4). Samples from Cabinda were taken at the littoral part where chemical weathering is not profound, whereas, in the interior part of the country (Huambo, Menongue) not only the rocks but the soils are highly weathered [30, 31]. Both studies by Wilford et al. [32] and Dickson and Scott [33] explain the influence of the weathering process and the topography on the radionuclide distribution [34]. Potassium is more easily weathered and leached out than radium in soils because of its higher solubility and probably hygroscopic feature. Moreover, upper horizons in soils are poor in potassium because of the plant uptake [35].

Contrariwise, to the results from the correlation between

${ }^{226} \mathrm{Ra}$ and ${ }^{40} \mathrm{~K}$, statistically significant relationship exists between ${ }^{232} \mathrm{Th}$ and ${ }^{40} \mathrm{~K}$ in Huambo and Menongue but not in Cabinda (Fig. 5). In some cases for instance when thorium is hydrated [27], the behavior of potassium and thorium is similar during the weathering process. In these cases, both elements are mobile during the weathering process as demonstrated on the study of Dickson and Scott [33]. Consequently, the average potassium and thorium content of soils reflect the average of the rocks content on the same elements from which they are derived. However, the differences in soil radioelement concentrations are relatively small [34].
Overall, the correlation among radionuclides is the strongest between ${ }^{226} \mathrm{Ra}$ and ${ }^{232} \mathrm{Th}$ in all areas which was also found in adobes and soils, for instance, by Szabó et al. [36] and El Afifi et al. [37]. However, as extensively demonstrated by Wilford et al. [32], in the study about different Australian soils, weathering processes and topography might have a big influence on the behavior of the radionuclides, consequently their distribution in the soil.

\section{Measured, calculated and estimated levels in this study}

\section{Activity compared to worldwide levels and to other countries with similar studies}

Because in Angola there are no studies about radiation of building materials, it was more adequate to compare the results of our study to similar materials in other countries (Table 3). In that regard, apart from adobe, we used soil, red-soil bricks, mud-bricks, soil and clay bricks because the conservation of the radionuclides content is similar considering that the manufacturing process does not change the initial composition of the building material [36]. It is also important to note that studies related to the radiological assessment of the adobe building materials are scarce. The worldwide median concentrations in soils (35, 30 and 400 $\mathrm{Bq} \mathrm{kg}{ }^{-1}$ for ${ }^{226} \mathrm{Ra},{ }^{232} \mathrm{Th}$ and ${ }^{40} \mathrm{~K}$, respectively) determined by UNSCEAR [7] will be used as reference values.

Amongst all the studied radionuclides, highest average values are found in Huambo, at the central part of the country (Fig. 2a-c). Measured activity concentrations of ${ }^{226} \mathrm{Ra}$ and ${ }^{232} \mathrm{Th}$ are lower in Cabinda $\left(26 \pm 7,36 \pm 5 \mathrm{~Bq} \mathrm{~kg}^{-1}\right)$ and Menongue $\left(27 \pm 10,30 \pm 10 \mathrm{~Bq} \mathrm{~kg}^{-1}\right)$ but more than two times higher in Huambo $\left(87 \pm 20,81 \pm 21 \mathrm{~Bq} \mathrm{~kg}^{-1}\right)$ than the reference values $\left(30,40 \mathrm{~Bq} \mathrm{~kg}^{-1}\right.$, [7], Fig. 2a, b). Regarding ${ }^{40} \mathrm{~K}$, all measured samples are below the reference ([7], Table 3).

Activity concentrations in this study are also comparable to those found in different studies from other countries as seen in Table 3. Average values of ${ }^{226} \mathrm{Ra}$ in Cabinda and Menongue are the same within standard deviation as Hungarian adobe [36], Australian mud-bricks [38], Bangladesh and Egyptian red clay bricks [39, 40], as well as Cameroonian and Spain soils [26, 41], whereas in Huambo they are higher. If the average is considered for all samples together $\left(47 \pm 30 \mathrm{~Bq} \mathrm{~kg}^{-1}\right)$, the value is higher than the world reference value (Table 3 ) raising the attention to a potential radiation risk if pore structure is advantageous for radon and thoron exhalation $[42,43]$. This is the topic of another paper in preparation of the authors.

Regarding the values of ${ }^{232}$ Th in Table 3, Huambo (central) belongs to the group with highest averages (above 81 $\left.\mathrm{Bq} \mathrm{kg}^{-1}\right)$. Cabinda and Menongue values are in the same 


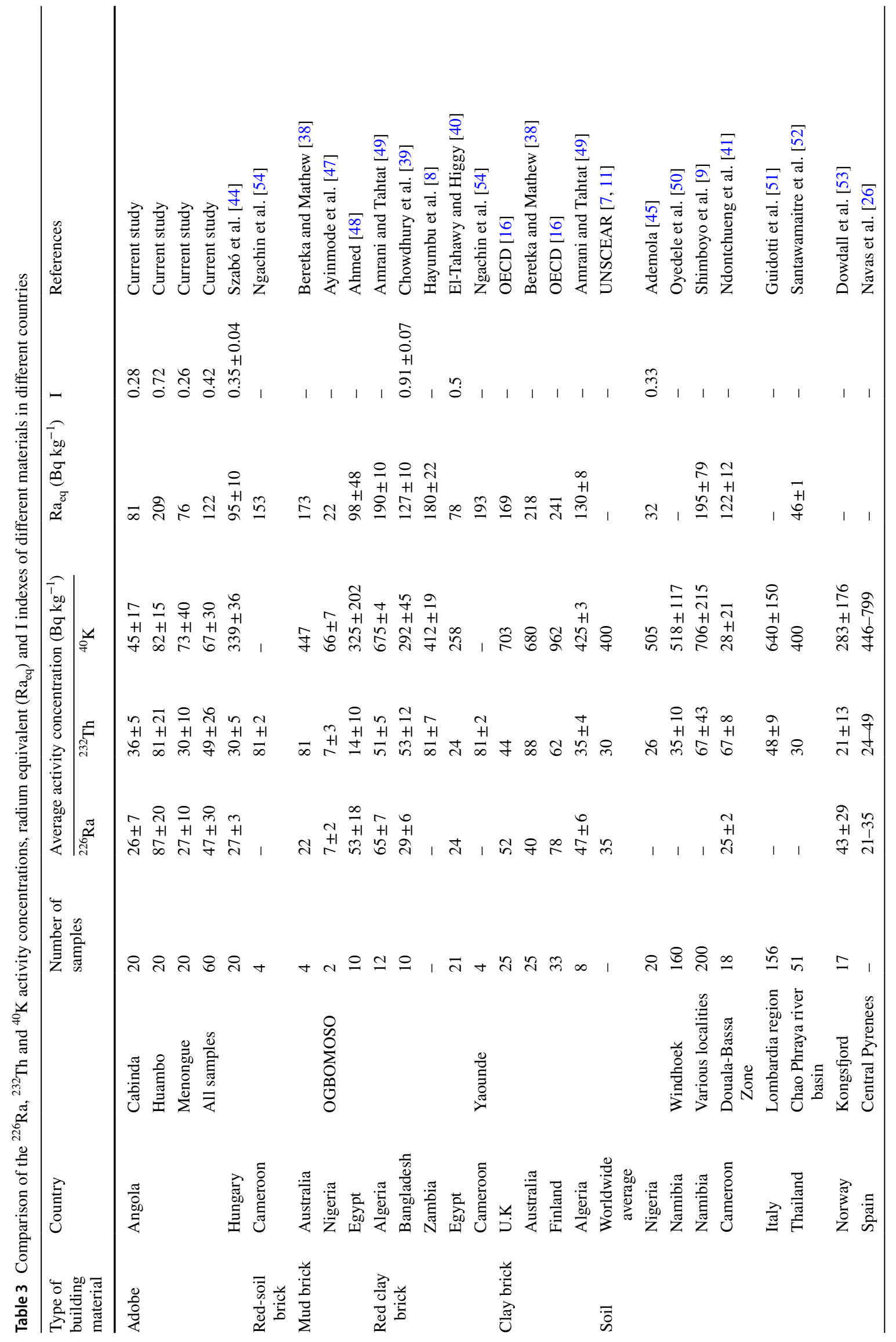


range as those from most of the countries but lower than the world reference value. The average of all samples together $\left(49 \pm 26 \mathrm{~Bq} \mathrm{~kg}^{-1}\right)$ is slightly higher than the reference value [7].

All activity concentrations of ${ }^{40} \mathrm{~K}$ from present study are much lower compared to most values contained in Table 3. The distribution of ${ }^{40} \mathrm{~K}$ can be highly variable because it can be controlled by physical processes such as soil redistribution (erosion/deposition) and by processes of leaching/ sorption in the soil complex [26, 32, 33]. These reveal significance of geology, local climatic conditions and physical processes which are crucial to the radionuclide distribution.

\section{Indexes compared to international and recommended limits}

Values of the Radium Equivalent Index, $\mathrm{Ra}_{\mathrm{eq}}$, are higher at the central part of the country (Huambo) and lower at the south part of the country (Menongue). None of the results is higher than the recommended value of $370 \mathrm{~Bq} \mathrm{~kg}^{-1}$ [16].

Values of $\mathrm{Ra}_{\mathrm{eq}}$ from the present study are compared to other countries as seen in Table 3. Values of the adobe from the central part (Huambo) are higher (209 $\mathrm{Bq} \mathrm{kg}_{-}^{-1}$; Fig. 6a) than most chosen reference countries, being only lower than the clay bricks from Finland (241 $\mathrm{Bq} \mathrm{kg}^{-1} ;$ [16]) and those from Australia (218 $\mathrm{Bq} \mathrm{kg}^{-1}$; [38]).

As for the I index, results from this study show average values three times higher in Huambo (0.72) than both other studied areas (Cabinda, 0.28 and Menongue, 0.26; Fig. 6b). All calculated values are lower than the recommended limit of 1 . However, some maxima values from Huambo (0.95, 0.94) are very close to the recommended limit (Fig. 6b). Comparing to other studies as shown in Table 3 , averages from the central part, Huambo, are just lower than the red clay bricks from Bangladesh (0.91; [39]) and higher than all others, whereas, from Cabinda (0.28) and Menongue (0.26) the averages are lower compared to all other studies (Table 3, Fig. 6b). If we consider the average of the I index for all samples (0.42), the value is higher than that of Hungarian adobes $(0.35)$ and Nigerian soils $(0.33)$ [44, 45], but lower than values found in other studies (Table 3, Fig. 6b).

\section{Measured and estimated effective doses}

The annual effective dose was determined according to two different procedures (Methods Section (f).). In one hand, it is calculated from the radionuclides activity concentration of the building material and the other hand, it is the result of an in situ measurement.

All the results of the estimated dose calculated from the radionuclides activity concentration of the building material are lower than the recommended limit of $1 \mathrm{mSv}$ year $^{-1}$ [7] (Fig. 7). However, results from the direct gamma dose rate measurement indicates that values measured in Huambo (1.5 mSv year ${ }^{-1}$; central part) and Menongue $\left(1.04 \mathrm{mSv}\right.$ year ${ }^{-1}$; south part) are higher than $1 \mathrm{mSv}$ year $^{-1}$ (Fig. 7).

In all cases measured values are higher than calculated ones by a ratio of 1.8, 1.9 and 3.9 in Cabinda (north), Huambo (central) and Menongue (south), respectively (Fig. 7). This indicates the influence of other sources than the building material, namely that of the cosmic rays and radionuclides from the soil [23, 46].

In other hand, if we compare AED-calculated results from Cabinda (north) and Menongue (south), we will find slightly higher values in the north $\left(0.4 \mathrm{mSv}_{\text {year }}{ }^{-1}\right.$ in Cabinda versus $0.3 \mathrm{mSv}_{\text {year }}{ }^{-1}$ in Menongue) but if we compare AED-measured results for the same areas, the north presents much higher values ( 0.6 in Cabinda versus $1.04 \mathrm{mSv}$ year $^{-1}$ in Menongue). The main difference between the areas is the altitude ( $1 \mathrm{~m}$ in Cabinda, $1354 \mathrm{~m}$ in Menongue). This is similar to the results of Achola et al. [12] who found very different ratios between the directly measured values and those calculated from radionuclide concentrations varying generally from 1.3 to 7.3 , and up to 45.5 in one particular case. Furthermore, it has also been demonstrated and confirmed by studies made in different parts of the world that dose exposure highly depends on the altitude [6].

\section{Conclusion}

From the three studied areas in Angola two, Cabinda (north) and Menongue (south) show ${ }^{226} \mathrm{Ra}$ and ${ }^{232} \mathrm{Th}$ activity concentrations in adobe building material in the same range as most international works focusing on similar type of materials. Whereas, Huambo (central) shows elevated values (116-49 and $121-39 \mathrm{~Bq} \mathrm{~kg}^{-1}$ for ${ }^{226} \mathrm{Ra}$ and ${ }^{232} \mathrm{Th}$ respectively). Regarding ${ }^{40} \mathrm{~K}$, values from all studied areas are low compared to other countries. From the correlations among the studied radionuclides, one may conclude that their geochemical behavior is an important factor determining their abundance. Based on the determined $\mathrm{Ra}_{\mathrm{eq}}$ and I building material qualification indexes, adobe building material from Angola is safe to use in radiological point of view. However, a closer look at the geology of the source material is strongly recommended when old metamorphic and igneous rocks, and their mechanical fragments are present. The annual effective doses showed different ranges for different methods of determination. Values determined from direct measurements are higher than those estimated from the activity concentrations of the building materials. It is because not only the geology influences the external radiation dose of the population living in adobe houses, but also the altitude of the settlement. 
Acknowledgements Open access funding provided by Eötvös Loránd University (ELTE). This project is financed by the Higher Education Department of the Angolan Army (FAA). J. Salupeto-Dembo is thankful for the support of all the members of the Lithosphere Fluid Research Lab of the University Eötvös Loránd University. The work of Zs. Szabó-Krausz is funded by the Premium Postdoctorate Research Program of the Hungarian Academy of Sciences. A big thanks to all the colleagues connected to this project from the Hungarian Academy of Sciences, Nuclear Security Department, Centre for Energy Research, especially to K.Zs. Szabó. Our thanks are extended to people in Angola who made possible the field campaign: Regue, Agostinho, Adelaide, Lelo, Mestre, Bruno, Bemba, Nangueve, Tio Bino, Sr Sapundo, Sr David, Fifi, and all the local people for their trust. We couldn't forget the special help from Mr. António Dembo and Mrs. Lizeth Pena. The authors are thankful for the work of the reviewer(s) and the editor. This is the 96th publication of the Lithosphere Fluid Research Laboratory (LRG), Eötvös University.

Open Access This article is distributed under the terms of the Creative Commons Attribution 4.0 International License (http://creativeco mmons.org/licenses/by/4.0/), which permits unrestricted use, distribution, and reproduction in any medium, provided you give appropriate credit to the original author(s) and the source, provide a link to the Creative Commons license, and indicate if changes were made.

\section{References}

1. Eisenbud M, Gesell TF (1997) Environmental radioactivity from natural, industrial, and military sources (4th Edition). Elsevier

2. UNSCEAR (2008) Annex B: exposures of the public and workers from various sources of radiation. In: UNSCEAR. Vol. I. Sources and effects of ionizing radiation, Report to the General Assembly with Scientific Annexes. New York

3. Trevisi R, Caricato A, D'Alessandro M, Fernández M, Leonardi F, Luches A, Tonnarini S, Veschetti M (2010) A pilot study on natural radioactivity in schools of south-east Italy. Env Int 36(3):276280. https://doi.org/10.1016/j.envint.2009.12.008

4. Council of the European Union (2013) Council Directive 2013/59/ Euratom. Off J Eur Union 56:216. https://doi.org/10.3000/19770 677.L_2013.124.eng

5. ICRP (2007) The 2007 Recommendations of the International Commission on Radiological Protection. ICRP Publication 103. https://doi.org/10.1016/j.icrp.2007.11.001

6. UNSCEAR (2008) Annex B: exposures of the public and workers from various sources of radiation. In: UNSCEAR. Vol. I. Sources and effects of ionizing radiation, Report to the General Assembly with Scientific Annexes. New York

7. UNSCEAR (2000) Annex B, Exposures from natural radiation sources. 83-156. In: UNSCEAR. Sources and effects of ionizing radiation, Report to the General Assembly with Scientific Annexes. New York

8. Hayumbu P, Zaman MB, Lubaba NCH, Munsanje SS, Muleya D (1995) Natural radioactivity in Zambian building materials collected from Lusaka. J Radioanal Nucl Chem 199:229-238. https ://doi.org/10.1007/BF02162371

9. Shimboyo SA, Oyedele JA, Sitoka SS (2016) Soil radioactivity levels and associated hazards in selected towns in uranium-rich Western Namibia. Int Sci Technol J Namibia ISTJN 2016 7:73-84

10. Ateba JFB, Ateba PO, Ben-Bolie GH, Abiama PE, Abega CR, Mvondo S (2010) Natural background dose measurements in South Cameroon. Radiat Prot Dosimetry 140:81-88. https://doi. org/10.1093/rpd/ncq035
11. UNSCEAR (2000) Annex A, Dose assessment methodologies. 19-82. In: UNSCEAR. Sources and effects of ionizing radiation, Report to the General Assembly with Scientific Annexes. New York

12. Achola SO, Patel JP, Mustapha AO, Angeyo HK (2012) Natural radioactivity and associated radiation characteristics of the new high background radiation area of Lambwe East. Southwestern Kenya. Radiat Prot Dosim 152(4):423-428. https://doi. org/10.1093/rpd/ncs047

13. Mustapha AO, Patel JP, Rathore IVS (1999) Assessment of human exposures to natural sources of radiation in Kenya. Radiat Prot Dosimetry 82:285-292. https://doi.org/10.1093/oxfordjournals. rpd.a032637

14. De Araújo AG (1992) Geologia de Angola: noticia explicativa da carta geológica à escala 1:1.000.000. Serviço Geológico de Angola, Luanda

15. Kis Z, Völgyesi P, Zs Szabó (2013) DÖME: revitalizing a lowbackground counting chamber and developing a radon-tight sample holder for gamma-ray spectroscopy measurements. J Radioanal Nucl Chem 298:2029-2035. https://doi.org/10.1007/ s10967-013-2691-8

16. OECD (1979) Report by a Group Experts of the OECD Nuclear Energy Agency, Exposure to radiation from the natural radioactivity in building materials. pp 40

17. European Commission (1999) Radiological protection principles concerning the natural radioactivity of building materials. Radiation Protection Report No. 112, Luxemburg, pp 16

18. Rodgers JL, Nicewander WA (1988) Thirteen ways to look at the correlation coefficient. Am Stat 42:59-66. https://doi. org/10.2307/2685263

19. Maxwell O, Wagiran H, Ibrahim N, Lee SK, Sabri S (2013) Comparison of activity concentration of ${ }^{238} \mathrm{U},{ }^{232} \mathrm{Th}$ and ${ }^{40} \mathrm{~K}$ in different Layers of subsurface Structures in Dei-Dei and Kubwa, Abuja, northcentral Nigeria. Radiat Phys Chem 91:70-80. https ://doi.org/10.1016/j.radphyschem.2013.05.006

20. Mehra R, Singh S, Singh K (2011) Assessment of the average effective dose from the analysis of ${ }^{226} \mathrm{Ra},{ }^{232} \mathrm{Th}$ and ${ }^{40} \mathrm{~K}$ in soil samples from Punjab, India. Geochem J 45:497-503

21. Odumo OB, Mustapha AO, Patel JP, Angeyo HK (2011) Radiological survey and assessment of associated activity concentration of the naturally occurring radioactive materials (NORM) in the Migori artisanal gold mining belt of southern Nyanza, Kenya. Appl Radiat Isot 69:912-916. https://doi.org/10.1016/j. apradiso.2011.02.016

22. Tzortzis M, Tsertos H, Christofides S, Christodoulides G (2003) Gamma-ray measurements of naturally occurring radioactive samples from Cyprus characteristic geological rocks. Radiat Meas 37:221-229. https://doi.org/10.1016/S1350 -4487(03)00028-3

23. Bossew P, Cinelli G, Hernandez-Ceballos M, Cernohlawek N, Gruber V, Dehandschutter B, Menneson F, Bleher M, Stohlker U, Hellmann I, Weiler F, Tollefsen T, Tognoli PV, de Cort M (2017) Estimating the terrestrial gamma dose rate by decomposition of the ambient dose equivalent rate. J Environ Radioact 166:296-308. https://doi.org/10.1016/j.jenvrad.2016.02.013

24. Szabó KZ, Jordan G, Petrik A, Horváth Á, Szabó C (2017) Spatial analysis of ambient gamma dose equivalent rate data by means of digital image processing techniques. J Environ Radioact 166:309320. https://doi.org/10.1016/j.jenvrad.2016.07.013

25. Torres SB, Petrik A, Szabó KZ, Jordan G, Yao J, Szabó C (2018) Spatial relationship between the field-measured ambient gamma dose equivalent rate and geological conditions in a granitic area, Velence Hills, Hungary: an application of digital spatial analysis methods. J Environ Radioact 192:267-278. https://doi. org/10.1016/j.jenvrad.2018.07.001 
26. Navas A, Gaspar L, Lopez-Vicente M, Machin J (2011) Spatial distribution of natural and artificial radionuclides at the catchment scale (South Central Pyrenees). Radiat Meas 46:261-269. https:// doi.org/10.1016/j.radmeas.2010.11.008

27. Bourdon B, Henderson GM, Lundstrom CC, Turner SP (2003) Volume 52: Uranium-series Geochemistry. Walter de Gruyter $\mathrm{GmbH} \& \mathrm{Co} \mathrm{KG}, 2018$

28. Fairbridge RW (1972) The encyclopedia of geochemistry and environmental sciences, Van Norstrand Reinhold, NY

29. Dequincey O, Chabaux F, Clauer N, Sigmarsson O, Liewig N, Leprun JC (2002) Chemical mobilizations in laterites: evidence from trace elements and ${ }^{238} \mathrm{U}-{ }^{234} \mathrm{U}-{ }^{230}$ Th disequilibria. Geochim Cosmochim Acta 66:1197-1210. https://doi.org/10.1016/S0016 -7037(01)00845-6

30. Diniz AC (1973) Características mesológicas de Angola descrição e correlação dos aspectos fisiográficos, dos solos e da vegetação das zonas agrícolas angolanas - Características mesológicas de Angola. Nova Lisboa: Missão de Inquéritos Agrícolas de Angola

31. Jones A, Breuning-Madsen H, Brossard M, Chapelle J, Dampha A, Deckers J, Dewitte O, Dondeyne S, Gallali T, Hallett S, Jones R, Kilasara M, Le Roux P, Micheli E, Montanarella L, Spaargaren O, Thiombiano L, Van Ranst E, Yemefack M, Zougmoré R (2015) Atlas Des Sols D' Afrique

32. Wilford JR, Bierwirth PN, Craig MA (1997) Application of airborne gamma-ray spectrometry in soil/regolith mapping and applied geomorphology. AGSO J Aust Geol Geophys 17(2):201-216

33. Dickson BL, Scott KM (1997) Interpretation of aerial gammaray surveys - adding the geochemical factors. AGSO J Aust Geol Geophys 17(2): 187-200

34. IAEA (2003) Guidelines for Radioelement Mapping Using Gamma Ray Spectrometry Data, IAEA-TECDOC-1363, IAEA, Vienna (2003)

35. Fujiyoshi R, Sawamura S (2004) Mesoscale variability of vertical profiles of environmental radionuclides $\left({ }^{40} \mathrm{~K},{ }^{226} \mathrm{Ra},{ }^{210} \mathrm{~Pb}\right.$ and ${ }^{137} \mathrm{Cs}$ ) in temperate forest soils in Germany. Sci Total Environ 320:177-188. https://doi.org/10.1016/j.scitotenv.2003.08.007

36. Szabó ZS (2013) Terrestrial radioactivity in Hungarian Adobe Building Material and Dwellings with a focus on Thoron (220Rn). PhD Thesis. Environ Phys Ph.D. Progr (Ádám Kiss, Imre Jánosi) Dr Sch Environ Sci, Eötvös University, Budapest, Hungary

37. El Afifi EM, Hilal MA, Khalifa SM, Aly HF (2006) Evaluation of $\mathrm{U}$, Th, $\mathrm{K}$ and emanated radon in some NORM and TENORM samples. Radiat Meas 41:627-633

38. Beretka JMP, Mathew PJ (1985) Natural radioactivity of Australian building materials, industrial wastes and by-products. Health Phys 48:87-95

39. Chowdhury MI, Alam MN, Ahmed AKS (1998) Concentration of radionuclides in building and ceramic materials of Bangladesh and evaluation of radiation hazard. J Radioanal Nucl Chem 231:117-122. https://doi.org/10.1007/BF02388016

40. El-Tahawy MS, Higgy RH (1995) Natural radioactivity in different types of bricks fabricated and used in the Cairo region. Appl Radiat Isot 46:1401-1406. https://doi.org/10.1016/09698043(95)00220-8
41. Ndontchueng MM, Nguelem MEJ, Simo A, Njinga RL, Gembou SCJ (2014) Gamma emitting radionuclides in soils from selected areas in Douala-Bassa Zone, Littoral region of Cameroon. ISRN Spectrosc 2014:1-8. https://doi.org/10.1155/2014/245125

42. Sas Z, Szántó J, Kovács J, Somlai J, Kovács T (2015) Influencing effect of heat-treatment on radon emanation and exhalation characteristic of red mud. J Environ Radioact 148:27-32. https:// doi.org/10.1016/j.jenvrad.2015.06.002

43. Meisenberg O, Tschiersch J (2011) Thoron in indoor air: modeling for a better exposure estimate. Indoor Air 21:240-252. https://doi. org/10.1111/j.1600-0668.2010.00697.x

44. Szabó ZS, Volgyesi P, Nagy HE, Szabó C, Kis Z, Csorba O (2013) Radioactivity of natural and artificial building materials-a comparative study. J Environ Radioact 118:64-74

45. Ademola AK, Bello AK, Adejumobi AC (2014) Determination of natural radioactivity and hazard in soil samples in and around gold mining area in Itagunmodi, south-western, Nigeria. J Radiat Res Appl Sci 7:249-255. https://doi.org/10.1016/j.jrras.2014.06.001

46. Beck H, De Planque G (1968) The radiation field in air due to distributed gamma-ray sources in the ground. HASL-195. HASL Rep. 1-53

47. Ayinmode BO, Famakinwa RO, Ajayi J (2012) Assessment of natural radioactivity in concrete block, extruded clay brick, and mud brick taken from Ogbomoso, Southwestern Nigeria. Anadolu Univ J Sci Technol 13:23-29

48. Ahmed NK (2005) Measurement of natural radioactivity in building materials in Qena city, Upper Egypt. J Environ Radioactivity 83(1):91-99

49. Amrani D, Tahtat M (2001) Natural radioactivity in Algerian building materials. Appl Radiat Isot 54(4):687-689

50. Oyedele JA (2006) Assessment of the natural radioactivity in the soils of Windhoek city, Namibia, Southern Africa. Radiat Prot Dosimetry 121(3):337-340

51. Guidotti L, Carini F, Rossi R, Gatti M, Cenci RM, Beone GM (2015) Gamma-spectrometric measurement of radioactivity in agricultural soils of the Lombardia region, northern Italy. J Environ Radioactivity 142:36-44

52. Santawamaitre T, Malain D, Al-Sulaiti HA, Bradley DA, Matthews MC, Regan PH (2014) Determination of 238U, 232Th and $40 \mathrm{~K}$ activity concentrations in riverbank soil along the Chao Phraya river basin in Thailand. J Environ Radioactivity 138:80-86

53. Dowdall M, Gerland S, Lind B (2003) Gamma-emitting natural and anthropogenic radionuclides in the terrestrial environment of Kongsfjord. Svalbard. Sci Total Environ 305(1-3):229-240

54. Ngachin M, Garavaglia M, Giovani C, Njock MGK, Nourreddine A (2007) Assessment of natural radioactivity and associated radiation hazards in some Cameroonian building materials. Radiat Measur 42(1):61-67

Publisher's Note Springer Nature remains neutral with regard to jurisdictional claims in published maps and institutional affiliations. 